\title{
Obsidian Sourcing in Bandung, Indonesia
}

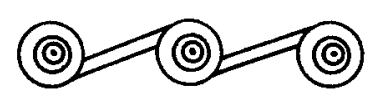

\author{
STEPHEN CHIA, LUFTI YONDRI, AND TRUMAN SIMANTUNJAK
}

\section{INTRODUCTION}

OBSIDIAN IS A NATURAL VOLCANIC GLASS, which was widely used during prehistoric times as cutting implements probably because it is shiny and attractive, and can be worked easily into implements with razor-sharp edges. Obsidian is formed through relatively fast cooling of high-silica lava domes and flows that are usually very homogeneous in chemical composition. The geological occurrence of obsidian is typically very limited and its homogeneous chemical composition is often highly characteristic of a particular source. Its relatively limited occurrence made it a valuable item of trade or exchange during prehistoric times. Although obsidian artifacts are brittle and have a short use-life, they are highly durable and can be found in archaeological sites over thousands of years old. As such, obsidian serves as an excellent material for studies in prehistoric sourcing, trade, or exchange.

In the last 30 years or so, research in the Mediterranean, the southwest Pacific and Southeast Asia have produced successful results using obsidian sourcing to extract information on prehistoric trade and exchange. This is mainly because linking obsidian artifacts to geographical sources can be successfully done using a wide range of techniques such as X-ray flourescence analysis, electron microprobe analysis, neutron activation analysis, proton-induced gamma-ray emission method, and proton-induced X-ray emission method (Ambrose et al. 1981; Bellwood 1989; Bellwood and Koon 1989; Bird et al. 1981; Chia 2003a, b; Duerden et al. 1987; Green 1987; Green and Bird 1989; Shackley 1998; Smith et al. 1977; Tykot 1998; Ward 1973; Williams-Thorpe 1995).

The islands of Indonesia, which possess active volcanic island arcs associated with explosive volcanism, have produced many obsidian sources. Some of these sources were exploited by prehistoric humans to make obsidian tools such as those in found in the Bandung region. However, many of the obsidian artifacts have yet to be chemically traced to known sources. This study is an attempt to trace the obsidian artifacts found at the sites of Gua Pawon, Dago, and Bukit Karsamanik in Bandung to some of the nearby and known sources in Nagreg and Garut.

Stephen Chia is affiliated with the Centre for Global Archaeological Research, Penang, Malaysia. Lufti Yondri is affiliated with Balai Arkeologi Bandung, Indonesia. Truman Simantunjak is affiliated with Kantor Asisten Deputi Urusan Arkeologi Nasional, Indonesia. 




Fig. 1. Distribution of obsidian artifacts and sources found in the Bandung Basin area.

\section{OBSIDIAN ARTIFACTS IN BANDUNG}

Obsidian artifacts have been discovered from a number of areas in the Bandung Basin, such as Padalarang, Pakar (southwest of Dago), Dago (KQ 380), north of Pasir Soang, Pasir Cikebi, west of Mount Tugu 2, northwest of Pasir Layung 2, south of Mount Cimenyan, Pasir Panyandakan (KQ 273), Mount Jatiluhur, Sekebunar, Cingiringsing, Pasir Luhur, west of Mount Cinangka area, and northwest of Pasir Pongkor, Lembang, Cicalengka, Banjaran, Soreang, Cililin, Bukit Karsamanik, and Gua Pawon (Fig. 1). The discovery of these obsidian artifacts have been reported by de Jong and von Koenigswald (1930), Krebs (1932-1933), Mohler and Rothpletz (1942-1945), van Stein Callenfels (1934), van der Hoop (1938), von Heine Geldern (1945), Bandi (1951), van Heekeren (1972), Nies Anggraeni (1978), Pantjawati (1988), Nurul Laili (2005), and Lutfi Yondri (2005). The precise dating of the obsidian artifacts found in these sites, however, remains mostly unknown due to the lack of chronometric dates. Nonetheless, earlier researchers such as von Koenigswald and van der Hoop classified these obsidian artifacts as implements dating to the Neolithic (cultivation) period based on the existence of pottery, square hatchet fragments, and metal printing; molds (Callenfels 1934; Hoop 1940; Koeningswald 1935). Others such as von Heine Geldern (1945), Bandi (1951), and Soejono (1984), however, preferred to classify the obsidian artifacts as artifacts from a pre-Neolithic period of hunting and gathering.

\section{Gua Pawon}

Gua Pawon (Pawon Cave) is located in the Cipatat district in the western plateau of the Bandung Basin area (see location in reference to other sites in Fig. 1). This 
cave is situated approximately $716 \mathrm{~m}$ above sea level in Mount Masigit, which is part of the Rajamandala limestone formation, consisting mostly of limestone and laminated limestone with foraminifera content (Sudjatmiko 1972, 2004). The Bandung Archaeological Research Bureau, in cooperation with the Board of Archaeological Heritage, History, and Traditional Values of West Java Province, carried out six seasons of excavations in Gua Pawon in July and October 2003, April 2004, and May 2004. The excavations revealed a wide variety of artifacts such as obsidian tools, bone tools, fragments of animal bones, mollusk remains, and human burials. A considerable amount of obsidian artifacts and waste material were found in Gua Pawon during the excavations. Most of the obsidian artifacts were found at depths between $20 \mathrm{~cm}$ and $60 \mathrm{~cm}$. The association of the other cultural artifacts with the obsidian artifacts and the radiocarbon dating of associated charcoal and bone samples placed the obsidian artifacts chronologically between 5600 B.P. and 9500 B.P. (Yondri 2004, 2005).

\section{Dago and Bukit Karsamanik}

Dago lies to the north of the Bandung basin area and Bandung town. It is situated about $723 \mathrm{~m}$ above sea level. The potential of Dago as a significant archaeological site is suggested by the discovery of a variety of artifacts from different cultural periods, such as Paleolithic stone implements, obsidian, pottery, and metal artifacts. Local villagers often report finding obsidian artifacts in Dago during farming or the construction of schools or housing estates. Bukit Karsamanik is located in the east of Bandung, near Mount Manglayang. Administratively this area is included in the district of Cileunyi, a sub-province of Bandung. Bukit Karsamanik lies about $720 \mathrm{~m}$ above sea level. At present, the area surrounding it is a nonirrigated dry field and a new region for housing development. Obsidian artifacts are usually found in this area during farming and land tilling.

\section{Obsidian Sources in Bandung}

Obsidian sources known in the Bandung region include Gunung Halu, Gunung Kendan (Nagreg), Gunung Kiamis and Kampung Rejeng (Garut), and Jampang (Sukabumi). Gunung Kendan is located near the Bandung Basin area while Gunung Halu is situated about $10 \mathrm{~km}$ to the west of Bandung. Kampung Rejeng and Gunung Kiamis are located about $100 \mathrm{~km}$ away east of Bandung, and Jampang about $70 \mathrm{~km}$ southwest of Bandung (Fig. 1).

Field visits were made to the known obsidian sources in Bandung and Nagreg to collect obsidian samples for the study, with the help of volcanologist Dr. Indyo Pratomo, and geologist Dr. Ayeng Hikmat from the Geological Museum in Bandung. Two major obsidian sources, namely Gunung Kendan in Nagreg and Kampung Rejeng near Kawah Drajat, Garut, located more than $100 \mathrm{~km}$ away from Bandung, were visited. Both Gunung Kendan and Kampung Rejeng were found to be large obsidian outcrops, which are still quarried by the local Sunda people who sell the obsidian rocks to ceramic producers. Samples of obsidian were collected from both these major source areas and chemical analyses of these samples were carried out in order to see if they match any of the obsidian artifacts found in Gua Pawon, Dago, and Bukit Karsamanik. 


\section{THE OBSIDIAN SAMPLES AND ANALYSES}

A total of 26 obsidian samples were used in this study-consisting of 21 pieces of obsidian artifacts and 5 obsidian source samples. Of the 21 pieces of obsidian artifacts, 12 pieces were selected from the excavated site of Gua Pawon conducted by Dr. Lufti Yondri, while 5 pieces were chance finds from Dago and another 4 pieces were chance finds from Bukit Karsamanik, provided by Dr. Truman Simantunjak. The 5 pieces of obsidian samples collected from the source areas used in this study comprised 3 samples from Gunung Kendan, Nagreg, and two samples from Kampung Rejeng at Kawah Drajat, Garut.

The 12 obsidian samples from Gua Pawon were selected from obsidian artifacts excavated from the undisturbed spits 1 to $14(160 \mathrm{~cm})$, radiocarbon dated between 5600 and 9500 B.P. (Yondri 2005). Obsidian artifacts were selected with different visible characteristics such as color, translucency, luster, and texture that might indicate different sources. This selection process was also done in order to reduce sample bias toward obsidian pieces produced from a single piece of core or a single source.

The majority of the samples were analyzed using a Scanning Electron Microscope (Model JEOL JSM-6460LV) equipped with Oxford INCA Energy 200 Energy Dispersive X-ray Spectrometer at the University of Science Malaysia in Penang. Some of the samples were also analyzed using the Cameca MBX Electron Microprobe using wavelength dispersive spectrometers at the University of Malaya, Kuala Lumpur. Both these methods were chosen mainly because they are minimally destructive (only $1 \mathrm{~mm}$ size sample is needed) and are relatively fast and accurate for determining the selected range of elements within the required detection limits, depending upon the element and composition of the sample. The range of elements that were detectable and selected included Si, Al, $\mathrm{Fe}, \mathrm{Ca}, \mathrm{K}, \mathrm{Na}$, and $\mathrm{O}$. These are among some of the most useful elements for distinguishing the known obsidian sources in Southeast Asia.

\section{DISCUSSION AND CONCLUSION}

Statistical examination of the elemental data revealed that the obsidian artifacts from Gua Pawon, Dago, and Bukit Karsamanik each formed their own groups. The Dago and Bukit Karsamanik samples form distinct groups but they tend to overlap, while the Gua Pawon samples are more dispersed or scattered (Figs. 24). The samples from Gua Pawon, however, appeared to fall within both the two known obsidian sources-Gunung Kendan in Nagreg and Kampung Rejeng in Garut. Both these sources also showed similar chemical compositions that are not distinguishable using the current set of elements (Table 1). A finer elemental discrimination, perhaps using other trace elements, could help to distinguish these two sources. There is a need for larger samples from these two sources and the other known source localities (especially Jampang, Gunung Halu, and Kiamis) in order to understand better the nature and degree of variability within and between the different sources. At present, the data suggests that the obsidian artifacts from Gua Pawon could possibly come from Nagreg or Garut or both.

The samples from Dago and Bukit Karsamanik, on the other hand, tend to overlap (Figs. 2-4), suggesting that they came from the same source(s). Both the 


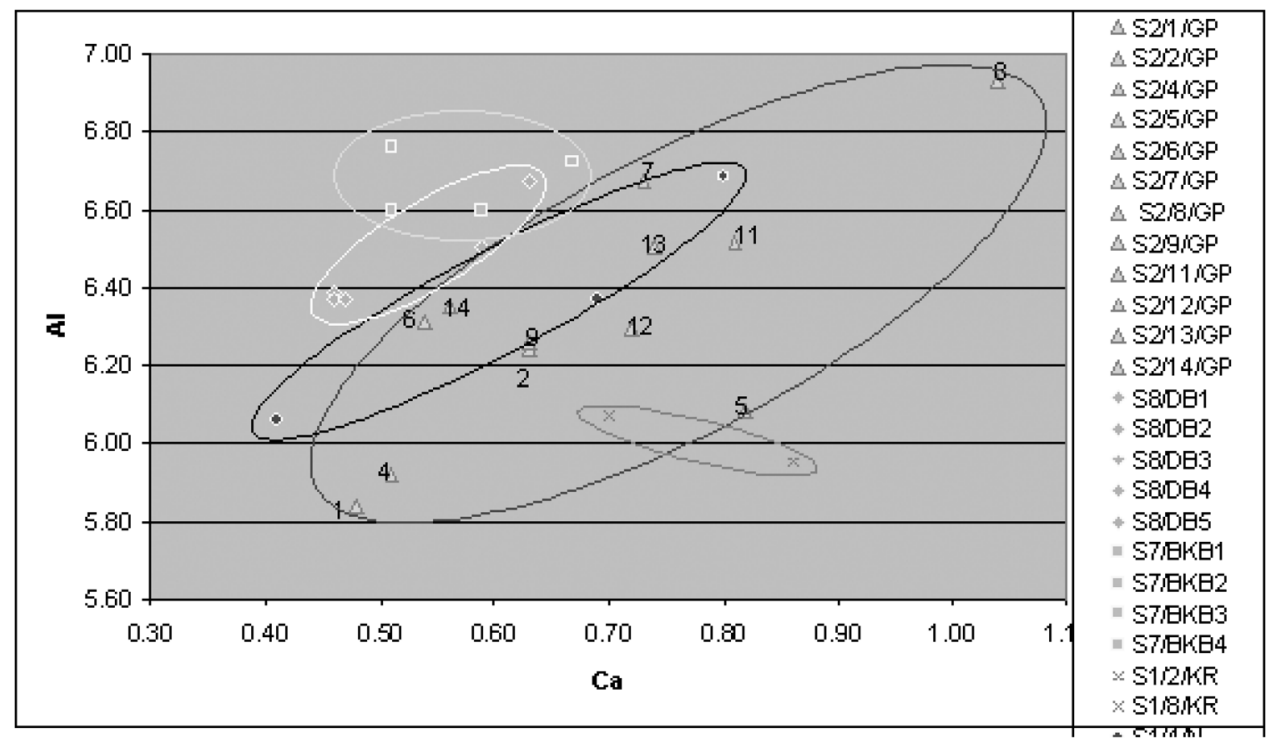

Fig. 2. Bivariate plot of $\mathrm{Al}$ versus $\mathrm{Ca}$.

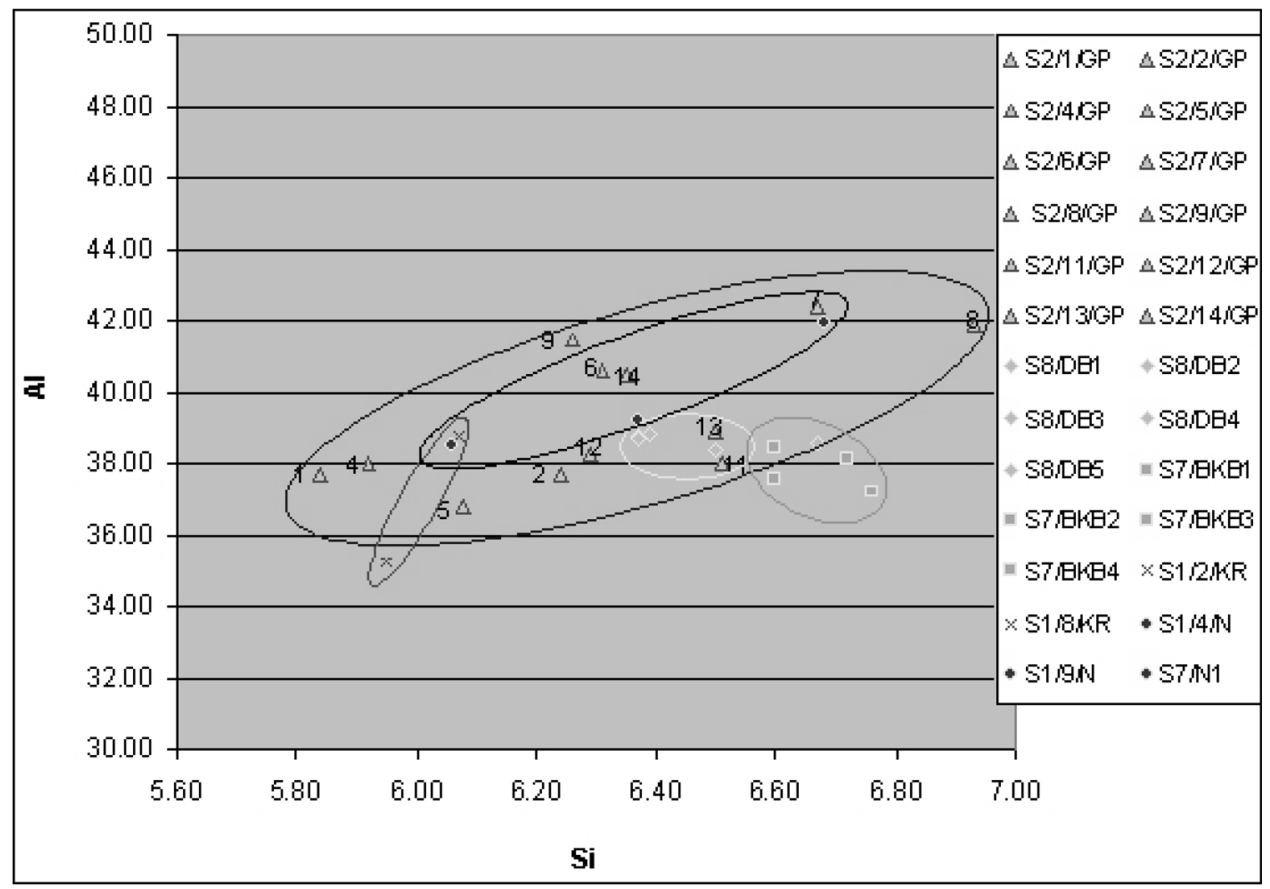

Fig. 3. Bivariate plot of $\mathrm{Al}$ versus Na. 


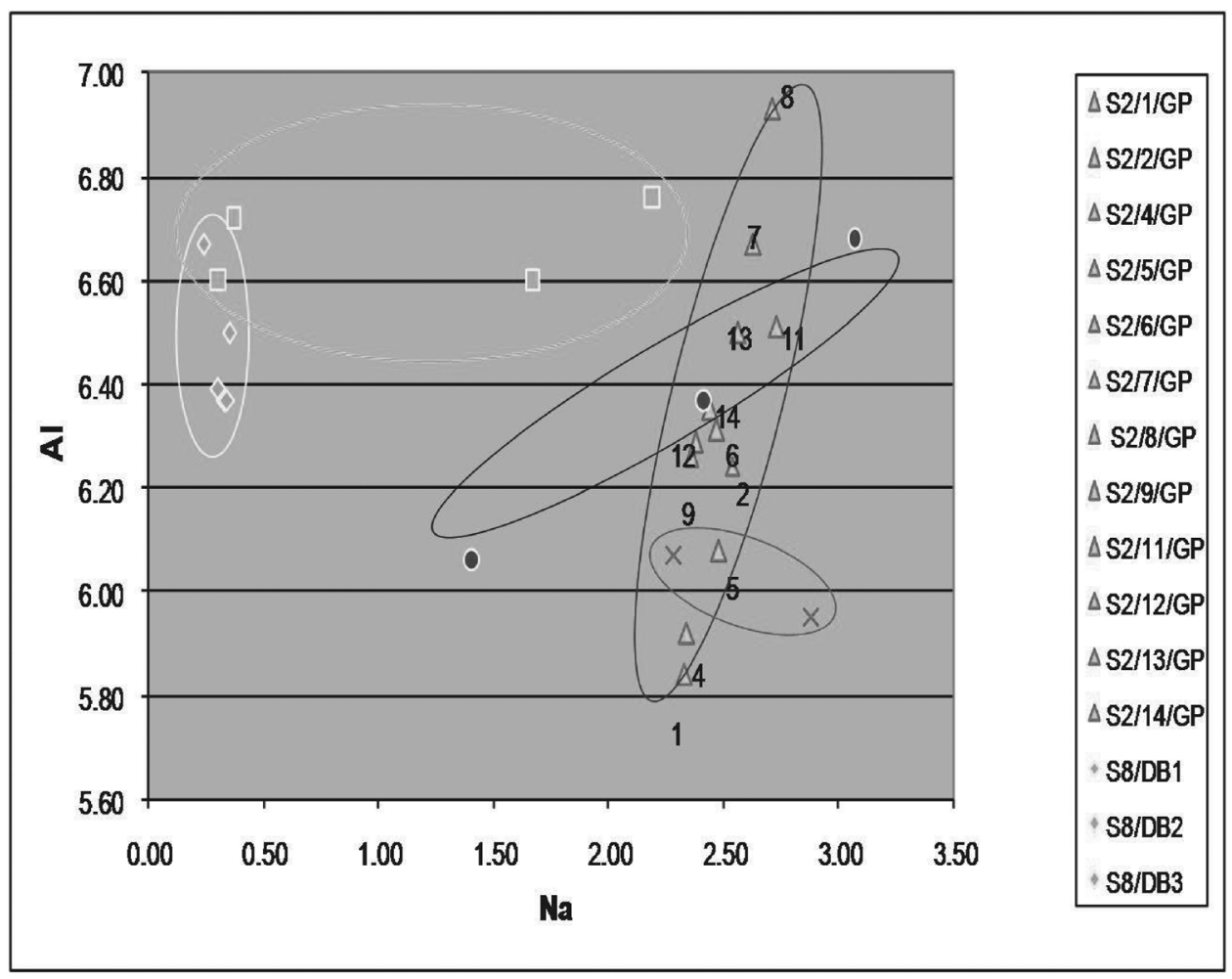

Fig. 4. Bivariate plot of Al versus Si.

Dago and Karsamanik samples, however, do not seem to fall within the two known obsidian sources of Gunung Kendan in Nagreg and Kampung Rejeng in Garut, suggesting that they were probably derived from other obsidian source(s). Again, more samples from these two known obsidian sources are needed to determine the variability within and between the obsidian sources in order to eliminate the possibility that the Dago and Bukit Karsamanik samples came from these two known sources. Temporally, the elemental data of the obsidian artifacts from Gua Pawon, which were sampled from different stratigraphical levels, were closely similar and tend to group together in the statistical examination (Figs. 2-4), suggesting that they were derived from the same source or similar sources over several thousands of years.

In conclusion, the results of the study suggest that the obsidian artifacts from Gua Pawon were made using obsidian obtained possibly from both the known obsidian sources of Gunung Kendan in Nagreg and Kampung Rejeng in Garut, while those from the sites of Dago and Bukit Karsamanik have yet to be determined. The Gunung Kendan and Kampung Rejeng sources were chemically very similar and therefore could not be distinguished. A finer discrimination using trace elements is recommended. In addition, more samples from these two sources and the other known sources of Jampang, Gunung Halu, and Kiamis are needed in order to determine the variability within and between these different 
Table i. Elemental Data of Obsidian Samples

\begin{tabular}{|c|c|c|c|c|c|c|c|c|}
\hline SAMPLE & LEVEL & $\mathrm{O}$ & $\mathrm{Na}$ & $\mathrm{Al}$ & $\mathrm{Si}$ & $\mathrm{K}$ & $\mathrm{Ca}$ & $\mathrm{Fe}$ \\
\hline $\mathrm{S} 2 / 1 / \mathrm{GP}$ & 1 & 49.13 & 2.33 & 5.84 & 37.69 & 3.85 & 0.48 & 0.71 \\
\hline $\mathrm{S} 2 / 2 / \mathrm{GP}$ & 2 & 49.00 & 2.54 & 6.24 & 37.67 & 3.16 & 0.63 & 0.78 \\
\hline $\mathrm{S} 2 / 4 / \mathrm{GP}$ & 4 & 48.38 & 2.34 & 5.92 & 38.03 & 3.88 & 0.51 & 0.64 \\
\hline $\mathrm{S} 2 / 5 / \mathrm{GP}$ & 5 & 46.89 & 2.48 & 6.08 & 36.74 & 3.12 & 0.82 & 0.70 \\
\hline $\mathrm{S} 2 / 6 / \mathrm{GP}$ & 6 & 45.07 & 2.47 & 6.31 & 40.59 & 4.03 & 0.54 & 0.87 \\
\hline $\mathrm{S} 2 / 7 / \mathrm{GP}$ & 7 & 43.28 & 2.63 & 6.67 & 42.39 & 3.54 & 0.73 & 0.79 \\
\hline $\mathrm{S} 2 / 8 / \mathrm{GP}$ & 8 & 43.01 & 2.71 & 6.93 & 41.89 & 3.39 & 1.04 & 1.05 \\
\hline $\mathrm{S} 2 / 9 / \mathrm{GP}$ & 9 & 44.45 & 2.36 & 6.26 & 41.43 & 4.05 & 0.63 & 0.68 \\
\hline S2/11/GP & 11 & 47.99 & 2.73 & 6.51 & 37.97 & 3.17 & 0.81 & 0.84 \\
\hline $\mathrm{S} 2 / 12 / \mathrm{GP}$ & 12 & 47.87 & 2.38 & 6.29 & 38.25 & 3.66 & 0.72 & 0.72 \\
\hline $\mathrm{S} 2 / 13 / \mathrm{GP}$ & 13 & 47.31 & 2.56 & 6.50 & 38.85 & 3.26 & 0.74 & 0.79 \\
\hline S2/14/GP & 14 & 45.30 & 2.44 & 6.35 & 40.49 & 4.14 & 0.56 & 0.74 \\
\hline S8/DB1 & Chance & 50.93 & 0.3 & 6.39 & 38.8 & 0.25 & 0.46 & 0.76 \\
\hline S8/DB2 & Chance & 50.88 & 0.33 & 6.37 & 38.74 & 2.37 & 0.46 & 0.7 \\
\hline S8/DB3 & Chance & 50.84 & 0.34 & 6.37 & 38.69 & 2.35 & 0.47 & 0.79 \\
\hline S8/DB4 & Chance & 50.71 & 0.35 & 6.5 & 38.37 & 2.44 & 0.59 & 0.83 \\
\hline S8/DB5 & Chance & 50.94 & 0.24 & 6.67 & 38.56 & 2.04 & 0.63 & 0.73 \\
\hline S7/BKB1 & Chance & 50.24 & 1.67 & 6.6 & 37.56 & 2.82 & 0.51 & 0.42 \\
\hline S7/BKB2 & Chance & 50.13 & 2.19 & 6.76 & 37.23 & 2.66 & 0.51 & 0.38 \\
\hline S7/BKB3 & Chance & 50.81 & 0.3 & 6.6 & 38.45 & 2.33 & 0.59 & 0.74 \\
\hline S7/BKB4 & Chance & 50.67 & 0.37 & 6.72 & 38.14 & 2.36 & 0.67 & 0.85 \\
\hline $\mathrm{S} 1 / 2 / \mathrm{KR}$ & Source & 47.22 & 2.28 & 6.07 & 38.71 & 3.94 & 0.70 & 0.80 \\
\hline $\mathrm{S} 1 / 8 / \mathrm{KR}$ & Source & 48.95 & 2.88 & 5.95 & 35.22 & 2.43 & 0.86 & 1.26 \\
\hline $\mathrm{S} 1 / 4 / \mathrm{N}$ & Source & 43.05 & 3.07 & 6.68 & 41.93 & 2.99 & 0.80 & 1.49 \\
\hline $\mathrm{S} 1 / 9 / \mathrm{N}$ & Source & 46.34 & 2.41 & 6.37 & 39.14 & 3.91 & 0.69 & 0.98 \\
\hline S7/N1 & Source & 50.61 & 1.4 & 6.06 & 38.48 & 2.4 & 0.41 & 0.47 \\
\hline
\end{tabular}

Note: $\mathrm{GP}=$ Gua Pawon; DB = Dago; BKB = Bukit Karsamanik; KR = Kampung Rejeng, Garut (Source); N = Gunung Kendan, Nagreg (Source).

sources. The study also indicated that prehistoric humans at Gua Pawon exploited the same obsidian resources over several thousands of years.

\section{ACKNOWLEDGMENTS}

We would like to thank Dr. Indyo Pratomo and Dr. Ayeng Hikmat of the Geological Museum Bandung, as well as Dr. Johan Arif and Ir. Budi Brahmantyo, M.Sc of the Institute of Technology Bandung for their kind help during the field visits to collect obsidian samples from the source areas in Bandung. Travel in Indonesia and analyses of the obsidian samples were made possible by the SEASREP regional collaboration grant.

\section{REFERENCES CITED}

Ambrose, W. R., J. R. Bird, and P. Duerden

1981 The impermanence of obsidian sources in Melanesia, in Archaeological Studies of Pacific Stone Resources: 1-19, ed. F. Leach and J. Davidson. Oxford: BAR International Series 104. 
BeLlwoOd, P.

1989 Archaeological investigations at Bukit Tengkorak and Segarong, southeastern Sabah. Bulletin of the Indo-Pacific Prehistory Association 9:122-162.

Bellwood, P., ANd P. Koon

1989 Lapita colonists leave boats unburned. Antiquity 63:613-622.

Bird, J. R., W. R. Ambrose, L. H. Russell, and M. D. Scott

1981 The Characterization of Melanesian Obsidian Sources and Artefacts Using the Proton-induced Gamma-ray Emission (PIGME) Technique. Lucas Heights: AAEC/E510, Australian Atomic Energy Commission.

CHIA, S.

2003a The Prehistory of Bukit Tengkorak as a Major Prehistoric Pottery Making site in Southeast Asia. Sabah Museum Monograph, Vol. 8, Kota Kinabalu, Malaysia.

$2003 b$ Obsidian sourcing at Bukit Tengkorak, Sabah, Malaysia. Sabah Society Journal 20 : 45-64.

Duerden, P., E. Clayton, J. R. Bird, W. R. Ambrose, and B. F. Leach.

1987 Obsidian composition catalogue, in Archaeometry: Further Australasian Studies: 232-238, ed. W. R. Ambrose and J.M.J. Mummery. Canberra: Department of Prehistory, Research School of Pacific Studies, Australian National University Publications.

Green, R. C.

1987 Obsidian results from Lapita sites of the Reef/Santa Cruz Islands, in Archaeometry: Further Australasian Studies: 239-249, ed. W. R. Ambrose and J.M.J. Mummery. Canberra: Department of Prehistory, Research School of Pacific Studies, Australian National University Publications.

Green, R. C., And J. R. Bird

1989 Fergusson Island obsidian from the D'Entrecasteaux group in the Lapita site of the Reef Santa Cruz group. New Zealand Journal of Archaeology 11: 87-99.

Laili, Nurul

2005 Sebaran Artefak Obsidian di Sisi Timur Laut Danau Bandung, Kota Bandung dan sekitarnya, Provinsi Jawa Barat. Laporan Hasil Penelitian Arkeologi.

ShaCKLEy, M. S., ED.

1998 Archaeological Obsidian Studies: Method and Theory. Advances in Archaeological and Museum Science Series, Vol. 3. New York: Plenum Press.

Smith, I.E.M., G. K. Ward, And W. R. Ambrose

1977 Geographical distribution and the characterisation of volcanic glasses in Oceania. Archaeology and Physical Anthropology in Oceania 12:173-201.

Sujaтміко

1972 Peta Geologi Lembar Cianjur Skala 1:100,000. Puslitbang Geologi Bandung.

2004 Sumber Alat-Alat Batu Prasejarah dari Situs Gua Pawon. Amanat Gua Pawon: 97-104.

Түкот, R. H.

1998 Mediterranean islands and multiple flows: The sources and exploitation of sardinian obsidian, in Method and theory in archaeological volcanic glass studies: 67-82, ed. M. S. Shackley. Advances in Archaeological and Museum Science Series. New York: Plenum Press.

WARD, G. K.

1973 Obsidian source localities in the north island of New Zealand. New Zealand Archaeological Association Newsletter 16:85-103.

Williams-Thorpe, O.

1995 Review article: Obsidian in the Mediterranean and the Near East: A provenance success story. Archaeometry 37(2):217-248.

YONDRI, LUTFI

2004 Situs Gua Pawon Dalam Lintasan Budaya Prasejarah Jawa Barat. Amanat Gua Pawon $1: 105-114$.

2005 Kubur Prasejarah Temuan dari Gua Pawon, Desa Gunung Masigit, Kabupaten Bandung-Jawa Barat; Sumbangan Data Bagi Kehidupan Prasejarah di tepian Danau Bandung Purba. Jakarta: Tesis. Fakultas Ilmu Budaya-Universitas Indonesia. 


\begin{abstract}
This article presents the results of a study to determine whether the obsidian artifacts found in Gua Pawon, Dago, and Bukit Karsamanik in Bandung came from the well-known sources of Gunung Kendan in Nagreg, Kampung Rejeng in Garut, or elsewhere. Obsidian artifacts for this study were obtained from earlier archaeological excavations at Gua Pawon and from chance finds at the sites of Dago and Bukit Karsamanik in Bandung. Samples of obsidian were also collected from the known obsidian sources in Gunung Kendan in Nagreg and Kampung Rejeng in Garut for comparative purposes. Analyses of these samples were done on a scanning electron microscope using the energy dispersive X-ray spectrometer at the University of Science Malaysia, Penang, and the electron microprobe at the University of Malaya, Kuala Lumpur. Multi-element analysis was undertaken, and statistical procedures were performed on data obtained from the artifacts and the sources. The results of the study thus far suggest that the obsidian artifacts from Gua Pawon were made using obsidian obtained from both Gunung Kendan and Kampung Rejeng sources, while those from Dago and Bukit Karsamanik have yet to be determined. More samples from all the known obsidian sources are needed to determine the variability within and between all the different sources. Temporally, the study also revealed that prehistoric humans at Gua Pawon exploited the same obsidian resources over several thousands of years. Keywords: Malaysia, obsidian, stone tools, Neolithic, chemical composition, sourcing.
\end{abstract}

